Article

\title{
Turning Indonesia Organic: Insights from Transdisciplinary Research on the Challenges of a Societal Transformation
}

\author{
Manuela Fritz ${ }^{1,2}$, Michael Grimm ${ }^{1,3,4, *} \mathbb{C}$, Patrick Keilbart ${ }^{5}$, Dimas Dwi Laksmana ${ }^{6} \mathbb{(}$, Nathalie Luck ${ }^{1}(\mathbb{D}$, \\ Martina Padmanabhan ${ }^{6}$, Nurcahyaningtyas Subandi ${ }^{7}$ and Kristian Tamtomo ${ }^{8}$ (D) \\ 1 School of Business, Economics and Information Systems, University of Passau, 94032 Passau, Germany; \\ manuela.fritz@uni-passau.de (M.F.); nathalie.luck@uni-passau.de (N.L.) \\ 2 Department of Economics, Econometrics and Finance, Faculty of Economics and Business, \\ University of Groningen, 9747 AE Groningen, The Netherlands \\ RWI Research Network, 45128 Essen, Germany \\ 4 IZA Bonn, 53113 Bonn, Germany \\ 5 Department of Southeast Asian Studies, Institute of East Asian Philology, Goethe University Frankfurt, \\ 60325 Frankfurt/M, Germany; keilbart@em.uni-frankfurt.de \\ 6 Faculty of Humanities, University of Passau, 94032 Passau, Germany; \\ dimas.dwilaksmana@uni-passau.de (D.D.L.); martina.padmanabhan@uni-passau.de (M.P.) \\ 7 Department of Development Economics, Universitas Atma Jaya Yogyakarta, \\ Daerah Istimewa Yogyakarta 55281, Indonesia; nurcahyaningtyas@uajy.ac.id \\ 8 Department of Sociology, Universitas Atma Jaya Yogyakarta, Daerah Istimewa Yogyakarta 55281, Indonesia; \\ kristian.tamtomo@uajy.ac.id \\ check for \\ * Correspondence: michael.grimm@uni-passau.de
}

updates

Citation: Fritz, M.; Grimm, M.; Keilbart, P.; Laksmana, D.D.; Luck, N.; Padmanabhan, M.; Subandi, N.; Tamtomo, K. Turning Indonesia Organic: Insights from

Transdisciplinary Research on the Challenges of a Societal

Transformation. Sustainability 2021,

13, 13011. https://doi.org/10.3390/ su132313011

Academic Editor: Roberto Mancinelli

Received: 20 September 2021

Accepted: 15 November 2021

Published: 24 November 2021

Publisher's Note: MDPI stays neutral with regard to jurisdictional claims in published maps and institutional affiliations.

Copyright: (c) 2021 by the authors. Licensee MDPI, Basel, Switzerland. This article is an open access article distributed under the terms and conditions of the Creative Commons Attribution (CC BY) license (https:/ / creativecommons.org/licenses/by/ $4.0 /)$.

\begin{abstract}
While there is a global consensus that agricultural systems need to be transformed to be more sustainable, possible pathways and challenges to this process are still debated. We analyse the challenges and opportunities involved in transforming smallholder farming to organic agriculture in Indonesia, where the intense application of Green Revolution technologies came at enormous environmental costs. We adopt a transdisciplinary approach to identify possible pathways towards organic agriculture, based on an analysis of farmers' knowledge and barriers to adoption, value and belief systems, and institutional structures, including policies and regulations. We present our empirical findings as 'system knowledge', 'target knowledge' and 'transformation knowledge' and incorporate insights from both academics and practitioners. We draw on evidence from large-scale surveys, field experiments, in-depth interviews, participant observation and document analysis. A key insight of our research is that Indonesia does not lack initiatives towards organic farming, but that these various initiatives have different motivations, goals and strategies. This misalignment detracts from the transformational potential of organic agriculture and is responsible for the hitherto limited success of the organic transition. Our findings suggest that policy action at multiple levels is required, guided by an inclusive strategy that is drawn up in a participatory manner.
\end{abstract}

Keywords: organic farming; transdisciplinarity; mixed-methods; technology adoption; Indonesia; sustainable agriculture; institutions

\section{Introduction}

Humanity faces unprecedented challenges due to climate change, increasing demand for food and the continuous depletion of natural resources, making the transformation to sustainable food production more urgent than ever [1]. Globally, except for Sub-Saharan Africa, agricultural development entailed a significant intensification in the use of chemical inputs, especially fertiliser and pesticides [2]. Intensive agriculture has contributed massively to global environmental change and the loss of important ecosystem services, for example due to the loss of biodiversity and decline in soil quality [3-5]. At the same time, agricultural production itself is threatened by these changes. For example, agriculture depends 
on biodiversity for the maintenance of genetic diversity, cultural identity, and essential ecosystem services, such as pollination, nutrient cycling and natural pest and disease control [6]. In this context, organic agriculture offers the potential to regenerate agricultural land and counteract biodiversity loss by abstaining from using chemical inputs and promoting practices such as crop rotation and vegetative buffer zones [7,8]. Simultaneously, it may also function as a sustainable pathway to poverty reduction for smallholder farmers [9]. Several studies indicate that organic agriculture can, in some contexts, positively impact smallholders' livelihoods due to the lower input costs and potential price premiums for organic food $[7,10]$. Nevertheless, organic agriculture remains a marginal activity. Only approximately 1.4 percent of total farmland worldwide is farmed organically, despite the increasing number of initiatives that promote such practices [11].

However, transforming to organic agriculture is not just a technical challenge; it also requires addressing constraints on access to information and technology [12-14], and socio-cultural and political challenges [15,16], while taking account of institutional contexts [17-19]. Instead of analysing these aspects of organic agriculture separately, we approach them as interconnected elements that, together, are essential for the generation of transformation knowledge (see also $[20,21])$.

This article synthesises the insights from IndORGANIC, an inter- and transdisciplinary research project that investigated the challenges and opportunities involved in transforming smallholder farming to organic agriculture in Indonesia. Indonesia offers a particularly interesting case study. Its current agricultural production system is characterised by persistently high levels of agrochemical inputs and faces severe environmental challenges. At the same time, government policies and civil society initiatives have increasingly engaged with organic agriculture over the past two decades [22,23], as has the German-Indonesian research consortium, IndORGANIC based at the University of Passau. This project was implemented over the period 2016 to 2020 and cooperated with three Indonesian institutions, Universitas Atma Jaya Yogyakarta (UAJY), Bogor Agricultural University (IPB), and the Indonesia Organic Alliance (Aliansi Organis Indonesia, AOI), an umbrella organization for organic agriculture in Indonesia. The project encompassed economic, anthropological, and sociological research, covering a range of topics, including farmers' knowledge, values and belief systems, barriers to adoption of organic agriculture, and the institutional context in Indonesia.

This article synthesizes the principal findings of the project and contributes to the literature on sustainable agriculture and transdisciplinary research in several regards. First, it presents findings from the application of transdisciplinary research methods to a real-world research project. This contrasts with the conceptual focus of much of the existing literature on transdisciplinarity $[24,25]$ and adds to a very recent but growing literature on transdisciplinary in sustainability research (see e.g., [26-30]). We present our empirical findings in the form of 'system knowledge', 'target knowledge' and 'transformation knowledge' [31] and use this framework to explore possible pathways to organic agriculture. Second, we incorporate the insights of both academics and practice partners involved in the project in our analysis to capture the complex relationships between stakeholders and broader institutional, cultural, and social conditions (see also [32]). Third, we use a wide range of research methods to provide a comprehensive analysis of the complex issues addressed by the project, combining data from large-scale surveys with in-depth interviews, participant observation, and policy analysis.

The remainder of this article is organized as follows. Section 2 describes the contextual conditions in Indonesia. Section 3 gives an overview of the combination of qualitative and quantitative methods applied in this project. Section 4 synthesizes our findings with regard to the three knowledge categories. Section 5 discusses the results and Section 6 concludes with policy recommendations and lessons for transdisciplinary research. 


\section{The Emergence of Organic Agriculture in Indonesia}

The beginnings of organic agriculture in Indonesia date back to the 1980s, when the first initiatives emerged in response to perceived negative impacts of the so-called Green Revolution. Indonesia adopted Green Revolution programs in the 1960s as a strategy for agricultural modernization, which was seen as key for maintaining both socio-economic stability and public support for Suharto's New Order government [33]. This centralized program focused on expanding agricultural production by implementing large-scale irrigation schemes and providing farmers with modern agricultural inputs such as high-yielding rice varieties, synthetic pesticides and fertilizers as well as extension support $[34,35]$. The intensification of agriculture led to a spike in agricultural production [34,36,37]; however, after peaking in the 1980s, agricultural growth rates stagnated between 1993 and 2000 [36,38]. Simatupang and Timmer [39] identify a number of ecological problems associated with the Green Revolution in Asia, including soil degradation and fatigue from over-farming (see also [40]). Thorburn [35] documents outbreaks of insect pests in 1985-1986 and in 2009-2011, caused in part by declines in the populations of natural predators due to the overuse of chemical pesticides.

Alongside this decline in agricultural growth rates, various studies also report socioeconomic problems associated with the Green Revolution program. Some studies report increased class differentiation among farmers adopting Green Revolution technologies, with benefits accruing to wealthier rural farmers and wealthier rural residents more generally [41-43]. There are also reports of farmers being forced to adopt Green Revolution inputs by government officials, and even by the army [44]. In summary, the intensive agriculture introduced by the Green Revolution in Indonesia was unsustainable, as evidenced by plateauing production due to the ecological impacts of intensive cropping, and increasing socio-political inequality, due in part to the centralised, state-led implementation of the program.

From the 1980s onwards, inspired by the growing international environmental movement, civil society initiatives throughout Indonesia promoted more sustainable forms of agriculture, marking the emergence of the organic agriculture movement in Indonesia. The Bina Sarana Bakti (BSB) Foundation, for example, established in 1984 in Bogor, West Java and initially supported by the Indonesian Catholic Church, was an important pioneer training centre which provided education and support for organic agriculture. This was followed, in the mid to late 1990s, by the formation of other organisations, including the BioTani Indonesia Foundation, Gita Pertiwi, the Seloliman Environmental Education Center (PPH Seloliman), the Serikat Petani dan Nelayan - Hari Pangan Sedunia (SPTN-HPS), the Sahani cooperative, and the Indonesian Development of Education and Permaculture (IDEP) Foundation [22,45,46]. Ultimately, an important breakthrough for the organic movement was the launch of the government's Integrated Pest Management (IPM) program in 1986, in response to advocacy by agricultural scientists and farmers during the brown planthopper outbreak that had started the previous year $[35,44,47]$. This was the first time that the organic movement had succeeded in influencing agricultural policy, which was by and large still dominated by the logic of the Green Revolution. The IPM program set up farmer field schools, where farmers received hands-on training in techniques informed by an agro-ecosystem perspective on agriculture [48]. The fall of Suharto in 1998 was a turning point in the history of organic agriculture. Existing organic organizations came together to form networks, which helped to further consolidate the organic movement [22]. These were, for example, the BioTani Foundation, PPH Seloliman, Gita Pertiwi and other organisations formed the Indonesian Organic Working Network (Jaringan Kerja Pertanian Organik Indonesia, Jaker-PO) in 1998 [46]. In 2000, staff from the Ministry of Agriculture (MoA) founded the Indonesian Organic Community (Masyarakat Pertanian Organik Indonesia, MAPORINA), while 2002 saw the foundation of AOI as well as the private organic certification company BIOCert [22,45]. These networks facilitated training and support of organic agriculture and played a leading role in the development of marketing initiatives, the participatory guarantee system PAMOR [49], community-based organic activities [50], and the documentation of community seed banks [51]. 
The post-Suharto period of reforms and political decentralization also led to increased government involvement in organic agriculture, which was now viewed as a potential market niche for Indonesian agriculture [52]. In 2001, the government launched the 'Go Organic $2010^{\prime}$ program, which sought to establish Indonesia as a leading exporter of organic food by 2010 through the development of an institutional infrastructure comprising socialisation programmes, technical assistance, regulation, certification, and market promotion $[46,53]$. In 2002, the government introduced the Indonesian National Standard for the organic food system. Among other measures, the new standard stipulated that organic labelling could only be used on products certified by an officially recognised certification body (Standar Nasional Indonesia). Since 2014, the promotion of organic agriculture has continued under Indonesia's current President Joko Widodo. In 2015, the MoA has launched the '1000 Organic Agriculture Villages' program, whose aim was to establish organic agriculture in villages across the country by the end of 2019 [54].

Despite almost three decades of civil society initiatives and government efforts to scale up its adoption, organic agriculture is still practised on only a small proportion of total agricultural land in Indonesia. The share of land devoted to organic agriculture is only 0.2 percent according to IFOAM data from Willer and Lernoud [11] and up to 0.86 percent based on AOI data in David and Ardiansyah [22]. This slow progress towards set goals is partly a reflection of over-ambitious policy objectives as well as persistent obstacles encountered by farmers in shifting to organic agriculture. Such obstacles include reduced yields during the transition process, limited knowledge of organic farming, lack of support from extension workers, lack of experience in the marketing of organic commodities, and the cost of organic certification [50,53,55-57].

This historical overview of the Green Revolution and the subsequent emergence of sustainable alternatives in Indonesia highlights that the development of organic agriculture began as a civil society movement and was only later taken up by the state in the postSuharto era. The different actor groups involved in organic agriculture define organic agriculture in different ways [54]. The pioneering civil society organisations see organic agriculture as a post-materialist enterprise explicitly directed towards social-political goals, that is at once a spiritual worldview, a practical philosophy, and a resistance movement opposed to the globalisation of capitalist agriculture. The Indonesian state adopts a narrower definition that reduces the diversity of meanings and traditions of organic farming by defining 'organic' as 'organically certified', privileging legal criteria over the agricultural practices that farmers engage in.

\section{Conceptual Framework and Applied Research Methods}

\subsection{Conceptual Framework}

Transdisciplinary research aims to have both societal and scientific impact. There is an emerging consensus that a transdisciplinary perspective on sustainability challenges is required for these to be effectively addressed [58]. Transdisciplinarity opens up new modes of interaction in binational and multinational research projects, while the mutual exchange of knowledge provides new insights into transformation strategies that can be shared with relevant stakeholders [59]. This approach to sustainability problems not only produces scientific knowledge but also generates practical solutions. In this article, we consider organic agriculture as a set of practices and guiding beliefs oriented towards the production of food within the limits of local nutrition cycles and with an explicit consideration of social and environmental justice.

The overall objective of this project was to identify the challenges and opportunities involved in 'turning agriculture organic' in Indonesia, as well as pathways towards achieving this goal. This research objective entailed addressing complex issues from a transdisciplinary perspective. An inclusive overarching methodological approach was required to synthesise findings from different disciplinary backgrounds into a coherent body of knowledge. We consciously took the decision to combine different qualitative and quantitative methods in order to meet this objective and to generate new insights. To align 
this project with the conceptual framework of transdisciplinary research as a knowledge generating process, the research approach was structured along three different knowledge types [31]: 'system knowledge', 'target knowledge', and 'transformation knowledge'.

System knowledge contributes to a multidimensional understanding of the current state. Target knowledge responds to the need for change by identifying the goals of important stakeholders, relating not only to technical aspects of sustainability, but also to corresponding belief systems and institutions. Since goals of different stakeholders may conflict with each other, trade-offs are a natural outcome [60]. Transformation knowledge identifies the changes that will be required to attain these goals, while seeking a consensus among contrasting interests. These necessary changes may include, for example, improved practices, conflict resolution, or a fundamental reconfiguration of society towards sustainability goals. Thus, transformation knowledge goes beyond descriptive analysis and considers the necessary conditions for change and the transition to sustainability [61]. It provides inputs for policy recommendations by identifying (in this case) technical, political, educational, or economic measures required to promote organic agriculture in Indonesia. In line with this conceptual framework based around these three types of knowledge, we derived three overarching research questions:

1. What is the current state of organic agriculture in Indonesia?

2. What are the aspirations of different stakeholders for the future of organic agriculture?

3. What are the possible pathways to organic agriculture?

We organised this research project into the three work packages (WP): 'Values', 'Institutions' and 'Adoption', with each package investigating a set of sub-questions encapsulating different aspects of the three overarching research questions. To address these questions, studies in each package applied different research methods, appropriate to the context and the stakeholders concerned.

The work package 'Values' (WP 1) explored the values and belief systems related to organic farming, focusing on the role of trade and potential markets for organic products. The work package 'Institutions' (WP2) focused on formal institutions and their roles in the policy arena of organic agriculture. The work package 'Adoption' (WP3) focused on farmers and consumers. The specific sub-questions that were addressed by each WP are summarised in Table 1.

Table 1. Sub-questions of the three work packages by knowledge type.

\begin{tabular}{|c|c|c|c|}
\hline Work Package & System Knowledge & Target Knowledge & Transformation Knowledge \\
\hline 1: Values & $\begin{array}{l}\text { Within which spiritual and } \\
\text { non-spiritual traditions is organic } \\
\text { farming located and what values } \\
\text { underlie attitudes of farmers towards } \\
\text { trade and certification? }\end{array}$ & $\begin{array}{l}\text { What are the aims of civil society } \\
\text { actors with regard to developing } \\
\text { markets and enhancing trade in } \\
\text { organic products? }\end{array}$ & $\begin{array}{l}\text { How can the socio-cultural values of civil } \\
\text { society actors be integrated into the } \\
\text { development of organic agriculture? }\end{array}$ \\
\hline 2: Institutions & $\begin{array}{l}\text { What governance structures are in } \\
\text { place to regulate organic agriculture? }\end{array}$ & $\begin{array}{c}\text { What are the aims of state and } \\
\text { non-state actors with regard of } \\
\text { organic agriculture? }\end{array}$ & $\begin{array}{l}\text { What policy strategies are suitable to } \\
\text { account for the diverse views by state and } \\
\text { non-state actors? }\end{array}$ \\
\hline 3: Adoption & $\begin{array}{c}\text { What do farmers know about organic } \\
\text { farming and what are their attitudes } \\
\text { towards it? } \\
\text { How much are consumers willing to } \\
\text { pay for organic food? }\end{array}$ & $\begin{array}{l}\text { What motivates farmers to } \\
\text { experiment with and ultimately } \\
\text { adopt organic farming? } \\
\text { What motivates consumers to buy } \\
\text { organic food? }\end{array}$ & $\begin{array}{l}\text { To what extent are information and } \\
\text { awareness raising campaigns and training } \\
\text { programmes effective in enhancing the } \\
\text { knowledge and adoption of organic } \\
\text { farming practices among farmers? } \\
\text { Can health and environmental awareness } \\
\text { campaigns increase consumers' } \\
\text { willingness to pay for organic food? }\end{array}$ \\
\hline
\end{tabular}

3.2. Research Methods: Combining Qualitative Stakeholder Interviews and Ethnographic Studies with Randomised Controlled Field Experiments

The research was mainly carried out within two regions of Java: in Tasikmalaya District in West Java Province and in the three districts Sleman, Bantul and Kulon Progo in Yogyakarta Province (see Figure 1). We selected these regions based on the capacity of our field partner AOI, who has a large number of actively engaged members in these 
two regions and could therefore implement organic farming training for 300 farmers in each region. Moreover, both regions share the characteristics of being important organic agricultural production areas, particularly for rice. Farmer groups in Tasikmalaya have succeeded in exporting organic rice [62], while the Yogyakarta region produces organic rice, vegetables, snake fruit and brown coconut sugar $[63,64]$. The research sites jointly have a population of 5.4 million inhabitants.

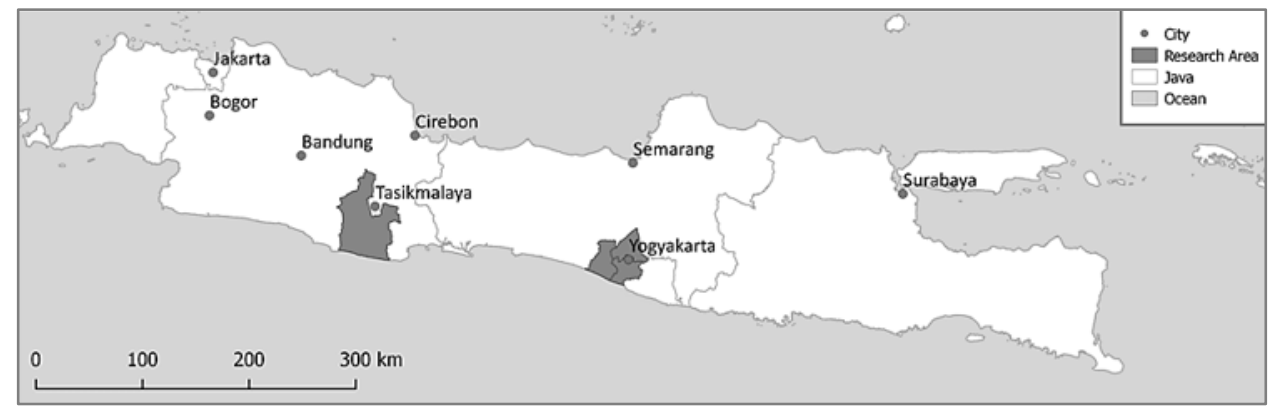

Figure 1. Field research sites on Java, Indonesia. Source: Own representation.

Figure 2 gives an overview of the research tools employed by the project. Although each work package has a clear focus, the boundaries between them are blurred. Each package also adds to the understanding of the wider context and the work packages mutually inform each other.

\begin{tabular}{|c|c|c|c|c|}
\hline WP 1 & \multicolumn{2}{|c|}{$\begin{array}{l}\text { In-depth semi-structured } \\
\text { interviews with civil society groups } \\
(\mathrm{n}=12)\end{array}$} & $\begin{array}{l}\text { Participant observations in villages } \\
\text { and within civil society groups } \\
\qquad(n=6)\end{array}$ & $\begin{array}{l}\text { Documentary research on civil } \\
\text { society groups }\end{array}$ \\
\hline WP 2 & \multicolumn{2}{|c|}{$\begin{array}{l}\text { Net-Map based on social network } \\
\text { analysis }(n=28)\end{array}$} & $\begin{array}{l}\text { Semi-structured interviews with } \\
\text { government officials and society } \\
\text { groups }(n=176)\end{array}$ & $\begin{array}{l}\text { Content analysis of policy } \\
\text { documents }\end{array}$ \\
\hline \multirow[t]{2}{*}{ WP 3} & \multirow{2}{*}{$\begin{array}{c}\text { Preparatory } \\
\text { qualitative } \\
\text { explorative field } \\
\text { work }\end{array}$} & \multirow{2}{*}{$\begin{array}{l}\text { Structured } \\
\text { quantitative } \\
\text { survey among } \\
\text { farmers } \\
\text { (baseline } \\
n=1,200 \text { ) }\end{array}$} & $\begin{array}{c}\text { Randomised controlled field } \\
\text { experiment with organic farming } \\
\text { training }(n=1,200)\end{array}$ & $\begin{array}{l}\text { Structured quantitative survey } \\
\text { among farmers (follow-up) }\end{array}$ \\
\hline & & & \multicolumn{2}{|c|}{$\begin{array}{l}\text { Willingness to Pay experiment and structured survey with consumers } \\
\qquad(\mathrm{n}=293)\end{array}$} \\
\hline
\end{tabular}

Figure 2. Research methods used by the IndORGANIC project. Source: Own representation.

WP1 'Values' primarily employed semi-structured interviews with key informants from civil society groups, engaged in participant observation, and conducted an extensive document review, especially of local (mainly grey) literature. The work package comprised two substantial phases of field research. In both phases, the researchers adopted a 'collaborative ethnography' approach [65], creating knowledge through collaboration with informants and consultants [66]. Outputs consisted of transcriptions and analyses of interviews, field notes, field diaries, as well as content and discourse analysis of documents related to the promotion and spread of organic farming knowledge, practices, and products.

The first phase of WP1 took place between September 2017 and February 2018 and focused on three civil society groups from Yogyakarta which are considered pioneers in the development of organic agriculture. Field research elicited narratives of the formation and development of these groups, recovered institutional memory of their foundational values, and captured their reaction to the trajectory of the Indonesian organic agriculture 
sector, particularly with regard to certification and trade. The researchers purposively sampled informants based on their role as administrators or key figures in each organisation. Narrative data was supplemented by observations of group activities and in-depth content and discourse analysis of a range of online and paper documents, including websites, brochures and trade labels. The second phase of field research was carried out in October and December 2018 in Yogyakarta and Tasikmalaya. This research investigated how and by whom value models are spread and become established, regionally and nationally. The researchers conducted in-depth qualitative interviews with key figures of six civil society groups and organisations in the two regions, covering Islamic, Christian and local cultural environmentalism. The interviews were complemented by participant observation.

WP2 'Institutions' combined two common sampling methods, namely purposive and snowball sampling. To cover the institutional environment of organic farming, both the Indonesian government and civil society groups were included. While the Ministry of Agriculture provided a sufficient sample in terms of government officials, policies and regulations, snowball sampling was especially useful in identifying networks of farmers and activists, and other influential civil society actors. The researchers conducted semi-structured interviews with government officials and civil society groups and an in-depth analysis of policy documents. The researchers interviewed a total of 176 respondents, including organic farmers, activists, NGO members, and governmental officials, particularly from the Department of Agriculture. The interviews and other interactions with respondents were documented in verbatim transcripts, field notes, and a research diary. These activities were complemented by a transdisciplinary workshop attended by 28 participants, including government officials, organic farmers, academics, and traders of organic products, to investigate their strategies for achieving their goals for organic agriculture. To recruit participants, we employed snowball sampling, especially among organic activists and local policy makers [67]. One outcome of the workshop was a NetMap-based analysis of social networks among stakeholders [68]. To further investigate decision making processes and aims among government agencies and NGOs in relation to organic agriculture, we analysed relevant academic literature and policy documents and carried out a content analysis of NGO publications and their internal documents.

WP3 'Adoption' primarily employed field experiments and structured surveys to derive causal evidence with respect to the research questions. Specifically, we used a randomised experiment to identify the effect of a three-day organic farming training course on farmers' uptake of organic inputs as well as on their knowledge and perception of organic farming (for details, see [69]). The experiment was conducted in both Tasikmalaya and Yogyakarta and encompassed a total of 60 randomly sampled villages, 30 from each research site. The researchers conducted baseline interviews and a follow-up survey with a total of 1200 farmers (20 farmer group members from each village). Following the baseline survey, we randomly assigned half of the villages (and farmers) to the treatment group while the other half formed the control group. After the baseline data collection, respondents in all treatment villages received an invitation to participate in an organic farming training. The training was designed jointly with AOI, who also delivered the training. It was designed to be largely participatory with hands-on training in organic fertiliser production, but also included some lecture classes on organic principles. We collected follow-up data one year after the baseline survey and around eleven months after the training. The follow-up survey also elicited information on networks and information exchange among trained farmers to learn more about the spread of information about organic farming and identify the individuals that serve as knowledge hubs within such networks. In a second study, a Willingness to Pay (WTP) experiment was conducted with 293 participants to explore what price premium consumers in urban and suburban areas are willing to pay for organic rice. The experiment consisted of an incentive-compatible auction based on the Becker-DeGroot-Marschak (BDM) approach (for details, see [70]). Given the urban context of the WTP experiment, it should be noted that the findings of 
this study are more likely to reflect the status quo in other urban Indonesian regions rather than rural areas (where rice is often self-produced).

\section{Inter and Transdisciplinary Research Findings on the Sustainability of Organic Farming}

\subsection{System Knowledge}

Regarding system knowledge of the values of organic civil society groups, we found that these values are situated within prevalent cultural traditions and are linked to specific views on organic trade and certification. Among civil society groups in West Java and Central Java, we identified three categories of value system, namely Islamic, Catholic, and local cultural agro-environmentalism. Islamic agro-environmentalism was represented by Islamic boarding schools in West Java and Central Java. These schools promote organic agriculture and support small-scale farmers against government-led large-scale agro-industrial projects [71]. Catholic agro-environmentalism was represented by a Catholic foundation and education facility that promotes ecological practices in West Java and a Catholic church and pilgrimage site in Central Java that teaches visitors about agroecology. Local cultural agro-environmentalism is represented by an official educational tourist site in West Java that preserves local Sundanese values to substantiate cultural agro-environmentalism and a cultural centre and tourist site in Central Java. In the latter, visitors and farmers are trained in Javanese philosophy related to local agro-environmentalism. In all three categories, shared values of a deep agro-ecology and organic lifestyle serve to promote eco-friendly small-scale production and consumption of local 'healthy' food. The common objective is to protect the environment- 'the creation' - and farmers' (food) sovereignty, recognising their agricultural values, knowledge, and technologies. However, organisations differ in how they relate to government initiatives. While some actors cooperate strategically with the government, others openly reject government control and the dominant agro-economic policy framework oriented towards free trade and large-scale agro-industrial production.

We also conducted case studies of three pioneers of organic agriculture in Yogyakarta: SPTN-HPS, the Sahani cooperative, and the Farmer Activists of Sleman. Founded in the 1990s, these were some of the first organisations to promote organic agriculture among farmer groups in the region. Their aims were to contribute both to environmental conservation and farmers' food sovereignty, while campaigning for greater equity in the political-economic structures of New Order agriculture policy. Nevertheless, reductions in external funding subsequently forced two groups, SPTN-HPS and Sahani, to adjust their values and practices in relation to trade in organic products. Specifically, these two groups are now open to participation in government-led organic certification schemes. Meanwhile, the third group continues to maintain its pioneer values and retains its critical stance towards large-scale trade in organic products, insisting that they should be marketed locally by community-based organisations.

The current institutional environment for organic farming is framed by the national standards, regulations and agencies set in place by the Indonesian government in the early 2000s. The MoA implements government policy on organic agriculture, supported by the Competent Authority for Organic Food (OKPO) and third-party certification bodies regulated by the National Accreditation Committee (KAN). The design of the latest national organic program ' 1000 Organic Agriculture Villages' comprises three components: (1) provision of technological packages and other inputs in the form of organic fertilisers, pesticides, and livestock for producing manure, (2) financial assistance for organic certification, and (3) knowledge transmission through farmer field schools (using externally recruited trainers in some project implementation areas). The principal function of the national MoA is to distribute financial resources to ministry offices at provincial and district levels. At the district level, ministry offices select farmer groups which could potentially obtain organic certification by the end of the program, taking account of the management capacity of the farmer groups, the history of land use in the area, and biophysical conditions such as water availability and climate. Only those farmers who are officially registered as farmers and farmer group members can take part in the program. Nevertheless, the scope 
of this program implementation is still unclear since there are still considerable knowledge gaps on organic agriculture among farmers.

Alongside the MoA, civil society groups play a variety of roles, contributing to knowledge sharing, marketing, and networking. The BSB Foundation, one of the early pioneers, was recently divided into two organisations, a training centre for knowledge sharing and a commercial branch which focuses on the production and marketing of organic products through a vegetable box distribution program. SPTN-HPS mainly focuses on providing organic agriculture training and setting up pilot projects in cooperation with village governors. Recently, this organisation also set up a participatory guarantee scheme in Yogyakarta as part of their marketing strategy. While these two organisations operate primarily at the regional level (though BSB also provides training throughout the country), AOI is an umbrella organisation that connects organic practitioners, private sector actors, and government agencies across the country. AOI has a networking function and actively engages in advocacy work to influence policies and regulations on organic agriculture.

At the farmer level, the baseline survey revealed considerable knowledge gaps and a heterogeneous perception towards organic farming and environmental consequences of agriculture. For instance, around 30\% of farmers interviewed in the baseline survey had never heard of organic farming and $78 \%$ were not aware of the existence of organic farming labels. Less than $20 \%$ of the interviewed farmers believed that demand for organic products has increased over the past five years, an important aspect if we believe that farmers are also motivated by the market potential of organic farming. Around $58 \%$ of farmers thought that farmers' decisions affect the environment. However, more than half of respondents (54\%) did not think (or at least were not willing to state) that agricultural pollution is an issue of concern. These results highlight that many farmers are still unaware of the interconnection between agriculture and the environment. In terms of current agricultural practices, the baseline survey indicated that around one-third of the farmers applied organic inputs such as processed manure or other types of organic fertiliser. However, these inputs were mostly applied in combination with chemical inputs. Overall, we would like to emphasize that this description of the current steady state is of course specific to our sample and we excluded known organic farmer groups from the sampling pool. We nevertheless believe it to be similar to the vast majority of farmer groups in Java as the number of excluded organic farmer groups was very small.

Results from our WTP experiment indicated that urban consumers in Yogyakarta are willing to pay an average price premium of $20 \%$ for organic rice compared to the non-organic rice they commonly purchased outside of the experiment. Around $44 \%$ offered a price equal or higher than the price commonly paid for certified organic rice at the farmgate in the time of survey in the study region and about $9 \%$ were willing to pay prices similar to those asked in supermarkets. Thus, there is a non-negligible local demand for organic food products. Yet expert interviews with producers in the study region indicated that they were at the time of the study oftentimes already unable to fulfill the increasing demand for organic food from supermarkets and private consumers. Not surprisingly, we found a strong positive relation between income and WTP, i.e., consumers with higher household income levels were willing to pay higher prices for organic rice. Consumers answers regarding their price expectation showed that they know that organic rice is more expensive than conventional rice; however, their 'offer' was well below the prices that they expected to prevail on the market.

Conclusively, civil society shapes the institutional environment of organic farming through networking and advocacy, marked by common values of deep ecology and organic lifestyle but differing cultural traditions. Meanwhile, governmental initiatives shape it through issuing regulations and standards. Nevertheless, knowledge gaps and a diverse perception towards organic farming prevail among smallholder-farmers, hindering the adoption process. There seems to exist a demand for organic rice, indicated by urban consumers' willingness to pay a price premium. While the offered price was mostly well 
below prices prevailing in supermarkets, a substantial share of consumers was willing to pay a price commonly asked at the farmgate.

\subsection{Target Knowledge}

The research on organic civil society groups revealed two major strands of values in relation to the development of organic trade. The first strand, represented by the farmer activists in Sleman and the Islamic agro-environmentalist boarding school in West Java, retains the holistic ideals of the organic farming pioneers and their vision of a communitybased organic farming system. These groups are dissatisfied with the current trend towards alignment of organic trade with conventional agri-food market structures. In their view, this market integration tends to foster inequality. Instead, they envision a deep ecologically oriented organic farming system emphasising farmer sovereignty and alternative community-based marketing. They are unwilling to compromise on their commitment to family farming and local organic markets as the only environmentally and socially just agricultural system. In this value constellation, reconciliation of these actors' deep ecological ideals with a broader organic market framework seems very unlikely. The creation of incentives for engaging in the local organic market through alternative agri-food arrangements such as participatory guarantee schemes, community markets, and delivery of organic produce directly to local consumers, could initiate a rapprochement. However, since these groups prioritise goals such as self-sufficiency, community building, and health benefits over income generation (see e.g., [72]), this strand tends to seek reform and an alternative organic market arrangement rather than a simple integration into the existing organic agri-food market arrangement.

The second strand is represented by SPTN-HPS, Sahani, and most of the other agroenvironmentalist groups in West and Central Java. Practitioners in these civil society groups envision an organic farming system that enables them to make profitable income, in addition to contributing to the goals of environmental sustainability and farmer sovereignty that were guiding principles of the early organic farming movement. These groups show similar directions of combining external and internal funding by encouraging farmers to set up small businesses to take advantage of new marketing opportunities and sell their organic products for a profit in local markets. Government support for certification and the development of marketing networks for organic agricultural products provides an additional incentive to those who wish to participate in the expanding organic market.

Although these two strands represent divergent reactions towards the expansion of organic markets, all groups surveyed expressed a shared aspiration for more equitable terms of trade, especially in dealing with traders, stores and supermarkets linked to the existing agri-food market [73].

To further examine the institutional framework for organic agriculture, we analysed the aims of state actors and how they differ from those of civil society actors [17,54]. According to the Indonesian National Standard [74], the aim of organic agriculture is to contribute to biodiversity conservation and environmental protection, taking account of agriculture's social, economic, and ethical dimensions. While this wording expresses a holistic understanding of organic agriculture, in practice, government initiatives such as the '1000 Organic Agriculture Villages' program follow a productivism- and market-oriented agenda with top-down decision-making under a decentralised government. Furthermore, as set out in the National Development Plan 2020-2024, the development of organic agriculture is measured by the growth in the market share of organic products. Between 2020 and 2024, the government aims to increase the market share of organic products from $5-20 \%$ of the total food market. However, in our research, we also met government officials from the Department of Agriculture with a more differentiated view of organic agriculture, who identified health of soils, the environment, and people as the key priorities.

Among civil society groups, we found diverse orientations. The community-based organisations associated with the organic movement tend to focus on grassroots activities, such as farmers' markets and knowledge sharing, to promote the holistic principle 
of organic agriculture and community building. The main aims of these actors are to empower organic farmers and to have greater control over organic agricultural inputs, by encouraging and teaching the use of locally available materials to make organic pesticides and fertilisers. Some NGOs also aim to improve the livelihoods of smallholder farmers, by strengthening their organisational and networking capacities to make it easier to access potential markets and government support. Since the early 2000s, the private sector tends to see the existing institutions in organic agriculture as source for a legal framework that allows access to a market for premium agricultural products. Therefore, these private sector actors focus on adherence to national and international organic standards to create national and international channels for marketing organic products.

A prerequisite for enhancing the adoption of organic agriculture is to understand the motivation of farmers to experiment with and ultimately adopt organic farming. Our research suggests that farmers' major concerns refer to production conditions and economic returns rather than environmental sustainability per se or independence from external inputs. Specifically, the majority of farmers who currently used organic inputs (but mostly applied it together with chemical inputs) reported that they were motivated mainly by the promise of improved soil conditions and resulting productivity gains. Farmers were also motivated by the expectation that organic farming practices would produce higher quality harvests.

In addition to famers' aims and motivations, our research also aimed to elicit consumers' motivations for buying and consuming organic food products. More specifically, we asked urban and suburban consumers in Yogyakarta about the considerations guiding their daily rice purchase decisions. They ranked high quality and good taste as the most important purchasing criteria in their daily food shopping. When asked what they perceived as the main benefits of organic food consumption, $83 \%$ mentioned health benefits, while environmental benefits and benefits for smallholder famers were only mentioned by $5 \%$ and $1 \%$ of respondents, respectively.

Overall, our research indicates that civil society groups, who are driven by deep ecology, envision alternative agri-food markets, whereas agro-environmentalist groups seek integration into the existing organic market, environmental sustainability, and farmer sovereignty. On the contrary, government's policies tend to emphasise the trade aspect of organic agriculture. In addition, the findings from the survey indicate that farmers motivations are driven by the desire to improve production conditions rather than by environmental concerns per se. However, farmers were also aware of the negative effects of conventional farming on soil conditions and expressed a desire to remedy this situation. Environmental benefits play only a minor role in consumers' purchasing decisions, whereas health aspects are overwhelmingly important.

\subsection{Transformation Knowledge}

Strategies and possible pathways towards organic agriculture have to be compatible with actors' values. Despite differences in knowledge and belief systems, civil society initiatives and non-government organisations face similar tensions and have to make similar trade-offs between their values on the one hand, and practical engagement with the market and the institutional structures of the agri-food market on the other. As described above, not all organic actors are able to reconcile their socio-ecological ideals with market expansion and the shift towards industrial-scale production. Some actively oppose these trends, promoting, as an alternative, short-chain and local-scale markets. Despite their opposition to prevailing trends, we suggest that these actors can still play important roles in developing sustainable organic agriculture in Indonesia. Some act as communicators of the underlying values that connect organic agriculture to wider issues of ecological and cultural sustainability $[50,71]$. This can help broaden the appeal of organic agriculture and ensure integration of knowledge across different value systems. Such civil society actors provide alternative spaces for social commentary that can balance the dominant market-oriented trajectory, for potential new forms of cooperation, and for articulation 
of wider social issues related to agriculture. These socio-cultural values can help organic agriculture to rediscover its roots as a holistic socio-ecological movement that proposes potential alternative pathways for Indonesian agriculture.

From an institutional perspective, strategies are required to enable a coherent development of organic agriculture that takes account of the diverse views of state actors and civil society groups. An overarching strategic framework is required that provides space for constructive negotiations and debates among different actors and accommodates the cultural and ecological diversity of farming communities across Indonesia. The decentralised structure of the Indonesian state provides a framework for decision making processes that are informed by the aspirations of farmers, NGOs and the private sector. Rather than seeking to reconcile the goals and motivations of different actors, the aim should be to create an institutional space that fosters dialogue and inclusive development. Individual actors often frame organic agriculture in one way, excluding other potential framings, i.e., either in economic terms or in terms of farmer sovereignty or social justice. In a functioning democracy, decentralisation can offer space for negotiation among these differing aspirations and views, and accommodate multiple trajectories in the development of organic agriculture.

The diversity of goals in organic agriculture raises a series of challenges that cannot be solved by the MoA alone. The development of organic agriculture raises environmental, trade, and logistical issues that require collaboration among different government ministries, both at the national and regional level, to formulate an 'organic agenda' and a plan for its implementation. This process should also involve civil society organisations at each step and should be open to public scrutiny. Finally, organic agriculture depends on local conditions and local knowledge. Although this important principle is stated in government regulations, in practice it has so far been largely neglected by government policy. We propose the creation of context-based organic farming guidelines that provide a framework for integrating local ecological conditions and knowledge. These guidelines, which should be drawn up jointly by the government and other actors, could facilitate the implementation of organic agriculture in different contexts and enhance mutual learning among actors.

Our field experiments offer interesting insights into adoption behaviour and provide inputs for the development of policies that can effectively enhance adoption of organic agriculture. The results showed that training and awareness raising increased the adoption of organic inputs, especially self-produced organic fertiliser. Specifically, we found that farmers assigned to the training group were on average 13\% more likely to use organic fertilizer and $8 \%$ more likely to use organic pesticide, compared to those in the control group. However, we found no significant effect of training on the use of chemical fertiliser, which remained high among farmers in the treatment group. Regarding knowledge and perceptions, we found that farmers who received training were more likely to answer questions about organic farming correctly (based on the training content) and to perceive organic farming as more profitable and modern than conventional farming. For example, farmers assigned to the treatment group were around $14 \%$ more likely to know about the prohibition of crop burning and around 20\% more likely to know about the requirement for a buffer zone between organically farmed land and conventionally farmed land. They also knew more about organic labels. Furthermore, the training increased farmers' awareness of the potential negative effects of chemical fertilizer and pesticides.

Overall, our findings suggest that information constraints are a barrier to the adoption of organic farming, and that the encouragement and the provision of hands-on training increase the uptake of organic farming inputs. We believe that, especially, three mechanisms can explain the success of our training intervention: First, the training was based on handson experimentation; second, organic farming was endorsed by an external expert and trainer; and third, the training was implemented at the group level (i.e., farmer group members participated jointly), which enhanced mutual learning and peer effects. However, as expected, we cannot yet observe complete conversion, partly owing to the short time period of our study. 
Our WTP experiment revealed that showing consumers a short video about health or, alternatively, environmental benefits of organic food was not effective in raising their WTP. However, the video about the environmental benefits of organic farming did have a positive effect on stated intentions to consume organic food. It was notable that $88 \%$ of respondents stated that certification is important. This highlights a potential difficulty for small-scale farmers, most of whom cannot afford to participate in official certification schemes. Alternative labels such as the participatory guarantee system promoted by some civil society actors could be a promising alternative. Finally, increasing the availability of organic rice at other retail outlets and traditional markets, where prices are lower than at supermarkets, could further boost the demand for organic products. Furthermore, increased competition could help to drive down the mark-ups that supermarkets currently apply.

In conclusion, civil society initiatives can position themselves as communicators of socio-cultural values and critics of the dominant market-oriented approach in organic farming. Furthermore, decentralization could foster dialogue among actors with different goals and facilitate cooperation across ministries. Our findings also reveal that, while information constraints are an important barrier to the adoption of organic farming practices, this can be addressed through hands-on and peer-group training. Lastly, increasing the availability of organic products at traditional markets could potentially increase the demand for organic products and decrease the currently high price mark-ups through increased competition.

\section{Discussion}

At the level of system knowledge, our synthesised findings on the current state of organic farming in Indonesia identify the state as the principal agent shaping the institutional environment, through the creation of a legislative framework and corresponding regulatory bodies under the MoA. National programmes to promote organic agriculture emphasise technology packages, distribution of inputs, knowledge transmission and financial support for obtaining certification. By channelling its intervention through the lower tiers of the agricultural administration, the government targets organised farmer groups, hoping for the positive externalities associated with collective action. Nevertheless, other studies in Indonesia suggest still limited state support for organic agriculture extension despite the existence of national organic programs [75-77], hence the persistent low level of adoption and knowledge of organic agriculture among farmers due to systematic constraints [78]. Meanwhile, civil society organisations continue to play a central role in knowledge transfer and innovation. However, the top-down approach gives rise to a functional separation between knowledge creators and regulators, restricting the potential for mutual feedback. Similar results due to restricted knowledge exchange have been observed in government run programmes to promote organic farming in Thailand [79].

In response to this separation, different groups within the organic movement have adopted two contrasting strategies towards the state. While some groups strategically engage with state programmes, for example by participating as trainers, others remain opposed to government control of the organic movement. Faith-based organisations often occupy a middle position between these two extremes. These organisations typically articulate a deep ecology perspective combined with concerns for social justice but do not necessarily reject cooperation with the state. Overall, three perspectives emerge [80]: (1) The critical-alternative perspective emphasises localised autonomous production and distribution of organic products; (2) the sustainable rural development perspective promotes community-based local trade; and (3) the business-minded perspective favours developing national and international trade. The tensions among these distinct perspectives in Indonesia mirror debates over the 'conventionalisation' of organic agriculture elsewhere in the world [15].

The baseline survey of farmers revealed knowledge gaps and a generally low level of awareness of the principles of organic farming. For example, very few farmers knew about organic labelling. Similarly, few believed that the demand for organic products has 
increased in recent years and more than half did not view agricultural pollution as an issue of concern. Somewhat in contrast to the low expectations by farmers, we found that urban consumers are willing to pay a considerable price premium of about $20 \%$ for organic rice. Furthermore, around $44 \%$ of consumers were willing to pay a price higher or equal to the price commonly asked by farmers at the farm gate. Given that many Indonesian consumers continue to buy rice at traditional markets or directly from the farmer, this is a relevant share. Interestingly, consumers were aware that organic products are more expensive, even though their offer price was mostly lower than their price expectations.

At the level of target knowledge, our results highlighted the diversity of aspirations for organic agriculture among different actors. Religious and traditional strands of agroenvironmentalism are united in striving for more equitable terms of trade for organic farmers. Social and ecological Islamic values are translated into the promotion of smallscale production and local marketing, and these values are spread via boarding schools and countrywide networks. Catholic agri-environmentalists support local farming practices and crop varieties for similar reasons, while remaining open to technological and scientific innovations. Both Islamic and Catholic organisations make links between Javanese and Sudanese cultural values and ecological sustainability. Groups drawing inspiration from deep ecology remain critical toward agri-business; others, in contrast, more inclined to cooperation, aim at developing markets in addition to achieving environmental and social goals. As Reuter [81] points out for Bali, ethical and economic motivations shape the idea of alternative agriculture.

The state's vision of organic agriculture also contains contradictory elements. At first glance the government follows a market-oriented agenda, adopts a top-down approach to its implementation (taking advantage of the structures and degrees of freedom of a decentralised system), and measures its success in terms of the market share. However, the national standard on organic farming also identifies soil health, the environment, and the people's wellbeing as its main aims. This more holistic vision of agriculture gives the possibility of defining broader measures of success.

Understanding farmers' motivations for adopting and continuing to practice organic farming is essential to boost the adoption of farming practices. Farmers stressed the importance of economic viability. A key motivation for adopting organic farming methods was the belief that they would enhance the quality and quantity of production by improving soil structure and fertility. Farmers stated that they were concerned by declining soil conditions; thus, the benefits in terms of improved soil quality-a by-product of using organic fertiliser such as processed manure-provide a promising entry point for promoting organic farming. Our research found that consumers were motivated to buy organic rice by considerations of quality and taste and, above all, the perceived health benefits of consuming organic products. This far outstripped any other motivation for buying organic rice, such as concerns for the environment or social justice. Other studies on Indonesian consumers also report similar motivations (e.g., [82,83]), although Slamet et al. [84] note that environmental concerns can be significant particularly among urban residents with tertiary education.

In terms of transformation knowledge, and building on the above findings, we identified possible pathways for 'turning Indonesia organic'. Building upon the analysis of the current state and the diverse goals of the different actors involved, our findings highlight the need for an overarching framework and a communication platform that brings together the diverse actors and allows for constructive negotiation and political debate to incorporate innovations emerging out of practice [85]. In this respect, the decentralised structure of the Indonesian state has great potential to accommodate multiple aspirations and development trajectories. Cooperation across different levels of the MoA and between the MoA and other ministries can help broaden the scope of the transformation brought about by the adoption of organic farming. Last but not least, an emphasis on local solutions could enhance contextualised mutual learning. 
The randomised field experiment with farmers provided evidence of the potential benefits of training. A clear outcome was that information constraints are a barrier to the adoption of organic farming practices in the local context. The positive impact of information provision on adoption is in line with findings from other studies investigating the adoption of sustainable agricultural practices (e.g., [86,87]). At the same time, there is a need for greater awareness of the negative effects of agrochemicals. Existing studies emphasise that the awareness of problems associated with the current practices, as well as the knowledge of appropriate farming techniques, are pre-requisite for the adoption of environmentally sustainable practices [88,89]. The impact of the training was likely enhanced by the emphasis on hands-on learning, the use of trusted expert trainers, and the peer effect of group trainings. Next to information constraints, other factors such as economic and credit constraints or risk aversion could be important barriers to the adoption of organic farming - these factors have been identified by previous studies for other agricultural technologies (for an overview see $[90,91]$ ). Given consumers' heightened awareness of health issues, more emphasis could be placed on the health benefits of organic foods, for example in certification schemes. The production of speciality rice varieties could help to justify the price premium for organic products.

\section{Conclusions: Policy Recommendations and Lessons of Transdisciplinary Research}

A key insight of our research is that Indonesia does not lack initiatives towards organic farming; however, the various initiatives have different motivations and different goals as well as unclear scope of actual implementation. The misalignment of interests and conflicts over strategies and values detracts from the transformational potential of organic agriculture and, combined with the unclear implementations of initiatives, is responsible for the hitherto limited success of the organic transition. Our findings suggest that, in order to realize the transformational potential, policy actions at multiple levels are required, guided by a strategy that is inclusive and developed with the participation of stakeholders.

National horizontal coordination-At the national level, it would help to intensify cooperation among the ministries directly and indirectly linked to the development of organic agricultural policies. Specifically, the MoA could consider a closer cooperation and coordination with the Ministry of Villages, the Ministry of Environment and Forestry, and the Ministry of Trade. The inclusion of civil society organisations could further facilitate the design of effective and more coherent organic farming policies.

National vertical coordination-The establishment of a communication platform that connects the diverse actors across civil society and the state, as well as farming communities and the private sector, as a space for constructive dialogue around the aims and methods of organic farming could further accompany such a process. In addition, such a platform could facilitate exchange of cultural and ecological knowledge among the highly diverse farming communities across Indonesia, for example, by building on the previous '1000 Organic Agriculture Villages' program.

Regional and local coordination-It could be useful to draw up contextualised organic farming guidelines for local actors. Such guidelines could, for example, outline the specific aspects of local agricultural knowledge, biophysical conditions, belief systems, and social organisations which are relevant for the implementation of organic farming policies in a given context. At a local level, civil society actors can act as value communicators, to ensure that relevant knowledge is incorporated into the contextualised guidelines. These guidelines can be used by extension workers, farmers, and scientists striving towards the common goal of organic transformation. Local government at the regency level can also play a crucial role, not only in supporting organic farmer groups but also in initiating cooperation and coordination between local state agencies, civil society and farmer groups (see for instance examples in [62] in Tasikmalaya and in [50] in Central Java).

We identified knowledge and information constraints as an important barrier towards the adoption of organic farming practices. We demonstrated that hands-on training and providing information on organic practices can overcome information constraints and 
enable farmers to make informed decisions on the adoption of specific practices. Training also changed farmers' perceptions of organic farming. Training courses could be integrated into existing extension activities or provided as stand-alone events. It is recommended to start by targeting farmer groups and villages that have already shown an interest in organic farming, as these are more likely to adopt organic practices. Successful experiences of these 'pioneers' can motivate and inform the adoption of organic practices by farmers in surrounding areas.

In addition to these policy recommendations, our research also contributes to the literature on transdisciplinarity. We followed [31] in using the categories of system, target and transformation knowledge, and demonstrate how a transdisciplinary framework can guide the synthesis of interdisciplinary findings.

We aligned the findings from development economics, social anthropology and institutional analysis to understand the current state of organic farming in Indonesia and the diversity of aspirations among stakeholders in order to identify promising pathways and strategies for organic transformation [92]. Transdisciplinary knowledge requires the acknowledgement of conflict and partiality, and a recognition of the need for compromise and collaboration in the development of contextualized strategies [93]. We demonstrated how discipline-specific research and transdisciplinary workshops involving policy makers, academics and civil society can overcome the difficulties inherent to 'complex systems science' [94] and arrive at a nuanced understanding and pragmatic policy recommendations.

We identified multiple definitions of organic agriculture and found it challenging to arrive at a shared understanding for operationalisation and evaluation. Similarly, Erbaugh et al. [95] describe transdisciplinary research on sustainable agricultural production in the tropics as a matter of definition, implementation and evaluation. They emphasise the need to tailor research to the geographical and temporal context, applying a definition of sustainability that can be translated into context-specific objectives that are relevant for local actors. With our specific focus on organic farming as a sustainable agricultural practice, we support their emphasis on hybrid governance as a mix of interventions through states, markets, and civil society.

Our findings contribute to the debate on behavioural change in the context of developmentfocused interventions. The research embraced the complexity of such behavioural change by adopting a transdisciplinary approach that considered individual knowledge and practices as embedded in larger conceptual frameworks of values, institutions and policies. We emphasise the value-orientation and normative foundations of decision-making processes among actors and stakeholders. Results from the rigorous evaluation of a training intervention combined with an institutional and policy analysis and ethnographic studies of underlying values and ethics underline that the adoption of organic farming practices is a complex social-ecological change process. An outcome of our transdisciplinary research is the conceptual framework for understanding this process based on the synthesis of interdisciplinary perspectives.

Despite these contributions our study also has some limitations which should be addressed in future research. First, due to our sampling strategy and study setting in Java, our results might not be easily transferred to other Indonesian regions or islands with different levels of agricultural activity or economic development. Future studies in the context of organic farming in Indonesia are therefore needed that investigate these aspects in different regions. Second, despite our Willingness to Pay experiment, the focus of our study was primarily on the producer side. This implies that we can make only limited conclusions in how to increase the demand for organic products in Indonesia. However, our Willingness to Pay experiment has highlighted the fact that information about environmental pollution positively influences the intention to buy more organic products. In-depth studies that analyze whether more intensive information campaigns can further increase the demand for organic products would be informative. Likewise, the role of health aspects in the demand for organic products should be investigated further. Third, as well as information constraints, other factors such as credit constraints 
or risk aversion could be important barriers to the adoption of organic farming and more longitudinal research is needed to assess these factors in the context of organic conversion.

Lastly, more research on constraints in horizontal and vertical coordination, in relation to the development of sustainable agriculture, is needed.

Author Contributions: Conceptualization, all authors contributed equally; Methodology, M.F., M.G., P.K., D.D.L., N.L., M.P. and K.T.; Formal Analysis M.F., M.G., P.K., D.D.L., N.L., M.P. and K.T.; Investigation M.F., P.K., D.D.L., N.L., M.P., N.S. and K.T.; Data curation, all authors contributed equally for their respective research areas; Writing-Original Draft M.F., M.G., P.K., D.D.L., N.L., M.P. and K.T.; Writing—Review \& editing M.F., M.G., P.K., D.D.L., N.L., M.P. and K.T.; Project Administration P.K., N.L. and N.S.; Funding Acquisition M.G. and M.P. All authors have read and agreed to the published version of the manuscript.

Funding: The authors acknowledge funding of the German Federal Ministry for Research and Education (Grant no. 031B0233, Research for Sustainable Development, funding line 'Bioeconomy as societal transformation').

Institutional Review Board Statement: The study was conducted according to the guidelines of the Declaration of Helsinki. The entire research programme and each individual researchers received approval by the Indonesia Ministry of Research and Technology (RISTEK). The part of the research involving large scale surveys and field experiments was in addition approved by the Ethics Committee of the University of Passau (protocol code I-07.5090/2021, 14 January 2021).

Informed Consent Statement: Informed consent was obtained from all subjects involved in the study.

Data Availability Statement: The data collected as part of the work packages 1 and 2 is only available on request from the corresponding author. The data are not publicly available in order to ensure confidentiality for the protection of informants, who might face negative consequences of the use of information contained. The data collected as part of the work package 3 will be made available in an anonymized format through a publicly accessible data repository after full completion of the research project. Further information can be obtained from the corresponding author.

Acknowledgments: The time and effort of all interview partners in Indonesia and the critical feedback from participants at the three transdisciplinary IndORGANIC workshops is highly appreciated. We would further like to thank Ronja Platz, Sarah Redicker and Franziska Steinhübel for excellent research assistance.

Conflicts of Interest: The authors declare no conflict of interest.

\section{References}

1. Willett, W.; Rockström, J.; Loken, B.; Springmann, M.; Lang, T.; Vermeulen, S.; Garnett, T.; Fan, S. Food in the Anthropocene: The EAT-Lancet Commission on healthy diets from sustainable food systems. Lancet 2019, 393, 447-492. [CrossRef]

2. Liu, Y.; Pan, X.; Li, J. A 1961-2010 record of fertilizer use, pesticide application and cereal yields: A review. Agron. Sustain. Dev. 2014, 35, 83-93. [CrossRef]

3. FAO. The State of Food and Agriculture. Moving forward on Food Loss and Waste Reduction; Food and Agriculture Organization of the United Nations: Rome, Italy, 2019; Licence: CC BY-NC-SA 3.0 IGO. 2019. Available online: https://www.fao.org/3/CA6030EN/ CA6030EN.pdf (accessed on 10 November 2021).

4. FAO and ITPS. Status of the World's Soil Resources (SWSR)—Main Report; Food and Agriculture Organization of the United Nations and Intergovernmental Technical Panel on Soils: Rome, Italy, 2015. Available online: https://www.fao.org/3/i5199e/i5199e.pdf (accessed on 10 November 2021).

5. IFAD. IFAD Annual Report 2013; International Fund for Agricultural Development: Rome, Italy, 2014. Available online: https: / / www.ifad.org/documents/38714170/40252718/AR_print_2013.pdf/47b6807c-7854--4ed6--9787-e0a2fb677323 (accessed on 10 November 2021).

6. IPBES. Global Assessment Report on Biodiversity and Ecosystem Services of the Intergovernmental Science-Policy Platform on Biodiversity and Ecosystem Services; Brondizio, E.S., Settele, J., Díaz, S., Ngo, H.T., Eds.; IPBES Secretariat: Bonn, Germany, 2019.

7. Jouzi, Z.; Azadi, H.; Taheri, F.; Zarafshani, K.; Gebrehiwot, K.; Van Passel, S.; Lebailly, P. Organic Farming and Small-Scale Farmers: Main Opportunities and Challenges. Ecol. Econ. 2017, 132, 144-154. [CrossRef]

8. Seufert, V. Organic Agriculture as an Opportunity for Sustainable Agricultural Development. Research to Practice Policy Briefs, 13. 2021. Available online: https:/ / www.mcgill.ca/isid/files/isid/seufert.pb13.pdf (accessed on 10 November 2021).

9. Eyhorn, F.; Berg, M.V.D.; Decock, C.; Maat, H.; Srivastava, A. Does Organic Farming Provide a Viable Alternative for Smallholder Rice Farmers in India? Sustainability 2018, 10, 4424. [CrossRef] 
10. Michler, J.D.; Baylis, K.; Arends-Kuenning, M.; Mazvimavi, K. Conservation agriculture and climate resilience. J. Environ. Econ. Manag. 2018, 93, 148-169. [CrossRef]

11. Willer, H.; Lernoud, J. (Eds.) The World of Organic Agriculture. Statistics and Emerging Trends 2019, 20th ed.; Research Institute of Organic Agriculture FiBL: Frick, Switzerland; IFOAM Organics International: Bonn, Germany, 2019.

12. Fafchamps, M.; Islam, A.; Malek, M.A.; Pakrashi, D. Can referral improve targeting? Evidence from an agricultural training experiment. J. Dev. Econ. 2020, 144, 102436. [CrossRef]

13. Genius, M.; Pantzios, C.J.; Tzouvelekas, V. Information Acquisition and Adoption of Organic Farming Practices. J. Agric. Resour. Econ. 2006, 31, 93-113.

14. Burton, M.; Rigby, D.; Young, T. Modelling the adoption of organic horticultural technology in the UK using Duration Analysis. Aust. J. Agric. Resour. Econ. 2003, 47, 29-54. [CrossRef]

15. Constance, D.H.; Choi, J.Y.; Lara, D. Engaging the Organic Conventionalization Debate. In Re-Thinking Organic Food and Farming in a Changing World; Freyer, B., Bingen, J., Eds.; Springer: Dordrecht, The Netherlands, 2015; pp. 161-185. [CrossRef]

16. Reed, M. Rebels for the Soil: The Rise of the Global Organic Food and Farming Movement; Earthscan: London, UK, 2010.

17. Laksmana, D.D.; Padmanabhan, M. Strategic Engagement in Institutions of Organic Farming in Indonesia. In Transitioning to Sustainable Life on Land, Transitioning to Sustainability Series 17; Beckmann, V., Ed.; MDPI: Basel, Switzerland, 2021; In Press.

18. Slavova, P.; Moschitz, H.; Georgieva, Z. Development of Organic Agriculture in Bulgaria (1990-2012): Actors, Relations, and Networks. Sociol. Rural. 2016, 57, 507-528. [CrossRef]

19. Mohan, S. Institutional Change in Value Chains: Evidence from Tea in Nepal. World Dev. 2016, 78, 52-65. [CrossRef]

20. Urmetzer, S.; Lask, J.; Vargas-Carpintero, R.; Pyka, A. Learning to change: Transformative knowledge for building a sustainable bioeconomy. Ecol. Econ. 2019, 167, 106435. [CrossRef]

21. Leach, M.; Rockström, J.; Raskin, P.; Scoones, I.; Stirling, A.C.; Smith, A.; Thompson, J.; Millstone, E.; Ely, A.; Arond, E.; et al. Transforming innovation for sustainability. Ecol. Soc. 2012, 17, 11. [CrossRef]

22. David, W.; Ardiansyah, N. Organic agriculture in Indonesia: Challenges and opportunities. Org. Agric. 2016, 7, 329-338. [CrossRef]

23. Matous, P. Social networks and environmental management at multiple levels: Soil conservation in Sumatra. Ecol. Soc. 2015, 20. [CrossRef]

24. Schäfer, M.; Kröger, M. Joint problem framing in sustainable land use research. Land Use Policy 2016, 57, 526-539. [CrossRef]

25. Defila, R.; Di Giulio, A. Integrating knowledge: Challenges raised by the "Inventory of Synthesis". Futures 2015, 65, 123-135. [CrossRef]

26. Dannecker, P. Transdisciplinarity 'Meets' Power Structures: Challenges and Experiences of a Capacity Building Project on Transdisciplinarity. Austrian J. South-East. Asian Stud. 2020, 13, 175-192. [CrossRef]

27. Dannecker, P.; Heis, A. 'Transdisciplinarity': A Framework of Knowledge Production in North-South Partnerships? Austrian J. South-East. Asian Stud. 2020, 13, 165-174. [CrossRef]

28. Osinski, A. Towards a Critical Sustainability Science? Participation of Disadvantaged Actors and Power Relations in Transdisciplinary Research. Sustainability 2021, 13, 1266. [CrossRef]

29. Nicli, S.; Elsen, S.; Bernhard, A. Eco-Social Agriculture for Social Transformation and Environmental Sustainability: A Case Study of the UPAS-Project. Sustainability 2020, 12, 5510. [CrossRef]

30. Tõnisson, L.; Kunz, Y.; Kecorius, S.; Madueño, L.; Tamayo, E.; Casanova, D.; Zhao, Q.; Schikowski, T.; Hornidge, A.-K.; Wiedensohler, A.; et al. From Transfer to Knowledge Co-Production: A Transdisciplinary Research Approach to Reduce Black Carbon Emissions in Metro Manila, Philippines. Sustainability 2020, 12, 10043. [CrossRef]

31. Hirsch Hadorn, G.; Hoffmann-Riem, H.; Biber-Klemm, S.; Grossenbacher-Mansuy, W.; Joye, D.; Pohl, C.; Wiesmann, U.; Zemp, E. (Eds.) Handbook of Transdisciplinary Research; Springer: Dodrecht, The Netherlands, 2008.

32. Lambe, F.; Ran, Y.; Jürisoo, M.; Holmlid, S.; Muhoza, C.; Johnson, O.; Osborne, M. Embracing complexity: A transdisciplinary conceptual framework for understanding behavior change in the context of development-focused interventions. World Dev. 2019, 126, 104703. [CrossRef]

33. Welker, M. The Green Revolution's ghost: Unruly subjects of participatory development in rural Indonesia. Am. Ethnol. 2012, 39, 389-406. [CrossRef]

34. Davidson, J. Then and Now: Campaigns to Achieve Rice Self-Sufficiency in Indonesia. J. Humanit. Soc. Sci. Southeast. Asia 2018, 174, 188-215. [CrossRef]

35. Thorburn, C. Empire Strikes Back: The Making and Unmaking of Indonesia's National Integrated Pest Management Program. Agroecol. Sustain. Food Syst. 2013, 38, 3-24. [CrossRef]

36. Fuglie, K.O. Productivity growth in Indonesian agriculture, 1961-2000. Bull. Indones. Econ. Stud. 2004, 40, 209-225. [CrossRef]

37. Booth, A. Agricultural Development in Indonesia; Allen and Unwin: Sydney, Australia, 1988.

38. Gérard, F.; Marty, I. The 1998 Food Crisis: Temporary Blip or the End of Food Security? In Agriculture in Crisis: People, Commodities, and Natural Resources in Indonesia, 1996-2000; Gerard, F., Ruf, F., Eds.; Curzon Press: Richmond, UK, 2001; pp. $269-300$.

39. Simatupang, P.; Timmer, C.P. Indonesian Rice Production: Policies and Realities. Bull. Indones. Econ. Stud. 2008, 44, 65-80. [CrossRef]

40. Pingali, O.; Hossain, M.; Gerpacio, R. Asian Rice Bowls: The Returning Crisis? CAB International: Wallingford, UK, 1997.

41. Pincus, J. Class, Power, and Agrarian Change: Land and Labour in Rural West. Java; Macmillan: London, UK, 1996. 
42. Huskens, F.; White, B. Java: Social Differentiation, Food Production, Agrarian Control. In Agrarian Transformations: Local Process and the State in Southeast Asia; Hart, G., Turton, A., White, B., Eds.; University of California Press: Berkeley, CA, USA, 1989 ; pp. $235-265$.

43. Hart, G. Power, Labor, and Livelihood: Processes of Change in Rural Java; University of California Press: Berkeley, CA, USA, 1986.

44. Röling, N.; van de Fliert, E. Transforming extension for sustainable agriculture: The case of integrated pest management in rice in Indonesia. Agric. Hum. Values 1994, 11, 96-108. [CrossRef]

45. Edwards, N. Values and the Institutionalization of Indonesia's Organic Agriculture Movement. In Social Activism in Southeast Asia; Ford, M., Ed.; Routledge: London, UK, 2013; pp. 72-88.

46. Jahroh, S. Organic Farming Development in Indonesia: Lessons Learned from Organic Farming in West Java and North Sumatra; ISDA: Montpellier, France, 2010; pp. 1-11, (hal-00521832).

47. Winarto, Y. Seeds of Knowledge: The Beginning of Integrated Pest. Management in Java; Yale University Southeast Asia Study: New Haven, CN, USA, 2004.

48. Fakih, M.; Rahardjo, T.; Pimbert, M. Community Integrated Pest. Management in Indonesia: Institutionalizing Participation and People Centred Approaches; International Institute for Environment and Development \& the Institute of Development Studies: London, UK, 2003.

49. AOI [Aliansi Organis Indonesia]. PAMOR, Penjaminan Mutu Organik Komunitas di Indonesia. 2017. Available online: http:/ / organicindonesia.org/aoi/pamor-penjaminan-mutu-organik-komunitas-di-indonesia (accessed on 27 January 2021).

50. Reuter, T.; MacRae, G. Regaining Lost Ground: A Social Movement for Sustainable Food Systems in Java, Indonesia. Anthropology of Food. 2019. Available online: http:/ /journals.openedition.org/aof/10292 (accessed on 18 July 2021).

51. Pramono, S.; Wangsit, S.; Dharmanta, E.; Krishnayanti, I.; Eka, N. Daulat Benih Daulat Petani: Benih Lokal Sebagai Pondasi Pertanian Organis; Aliansi Organis Indonesia: Bogor, Indonesia, 2020.

52. Hidayat, A.S.; Lesmana, T. The Development of Organic Rice Farming in Indonesia. Rev. Indones. Econ. Bus. Stud. 2011, 2, 71-87. Available online: https://jurnalekonomi.lipi.go.id/riebs/issue/view/13/14 (accessed on 13 July 2017).

53. Farmia, A. Development of Organic Rice Farming in a Rural Area, Bantul Regency, Yogyakarta Special Province, Indonesia. J. Dev. Sustain. Agric. 2008, 3, 135-148. [CrossRef]

54. Schreer, V.; Padmanabhan, M. The many meanings of organic farming: Framing food security and food sovereignty in Indonesia. Org. Agric. 2019, 10, 327-338. [CrossRef]

55. Mayrowani, H. Pengembangan Pertanian Organik di Indonesia. Forum Penelit. Agro Èkon. 2016, 30, 91-108. [CrossRef]

56. Macrae, G. Rice Farming in Bali. Crit. Asian Stud. 2011, 43, 69-92. [CrossRef]

57. Syaukat, Y. Socio-economic Assessment of Organic Farming in Bogor, West Java, Indonesia. J. Int. Soc. Southeast Asian Agric. Sci. 2008, 14, 49-60.

58. Lang, D.J.; Wiek, A.; Bergmann, M.; Stauffacher, M.; Martens, P.; Moll, P.; Swilling, M.; Thomas, C.J. Transdisciplinary research in sustainability science: Practice, principles, and challenges. Sustain. Sci. 2012, 7, 25-43. [CrossRef]

59. Woltersdorf, L.; Lang, P.; Döll, P. How to set up a transdisciplinary research project in Central Asia: Description and evaluation. Sustain. Sci. 2018, 14, 697-711. [CrossRef]

60. Nightingale, A.J. (Ed.) Environment and Sustainability in a Globalizing World; Routledge: London, UK, 2019. [CrossRef]

61. Padmanabhan, M. (Ed.) Transdisciplinary Research and Sustainability: Collaboration, Innovation and Transformation; Routledge: London, UK; Taylor \& Francis Group: London, UK, 2018.

62. Saliem, H.P.; Susilowati, S.H.; Ariningsih, E.; Agustian, A. Muksin Supporting organic rice exports: The success story of West Java organic rice exports. IOP Conf. Ser. Earth Environ. Sci. 2021, 672, 012095. [CrossRef]

63. Pratita, D.G.; Irham, I.; Mulyo, J.H. Entrepreneurship Competence Level of Organic Farmers in Yogyakarta Province. Agro Èkon. 2019, 29, 231-243. [CrossRef]

64. Wijayanti, D.E.; Hartono, S.; Darwanto, D.H. Relative Efficiency of Brown Sugar Agroindustry in Kokap District, Kulon Progo Regency, D.I. Yogyakarta. Agro Èkon. 2016, 27, 52. [CrossRef]

65. Rappaport, J. Beyond Participant Observation: Collaborative Ethnography as Theoretical Innovation. Collab. Anthr. 2008, 1, 1-31. [CrossRef]

66. Reyes, V. Ethnographic toolkit: Strategic positionality and researchers' visible and invisible tools in field research. Ethnography 2018, 21, 220-240. [CrossRef]

67. Flick, U. Desgning Qualitative Research; Sage: London, UK, 2018.

68. Schiffer, E.; Hauck, J. Net-Map: Collecting Social Network Data and Facilitating Network Learning through Participatory Influence Network Mapping. Field Methods 2010, 22, 231-249. [CrossRef]

69. Grimm, M.; Luck, N. Can Training Enhance Adoption, Knowledge and Perception of Organic Farming Practices? Evidence from a Randomized Experiment in Indonesia. IZA Discussion Paper 13400; IZA: Bonn, Germany, 2020.

70. Grimm, M.; Luck, N.; Steinhübel, F. Do Indonesian Consumers Value Organic Rice?_Evidence from an Incentive-Compatible Willingnessto-Pay Experiment, IndORGANIC Policy Brief; University of Passau: Passau, Germany, 2019.

71. Großmann, K. Green Islam: Islamic Environmentalism in Indonesia. New Mandala: New Perspectives on Southeast. Asia. 2019. Available online: https:/ / www.newmandala.org/green-islam/ (accessed on 26 March 2021).

72. Widiyanto, D. The Third Wave of Indonesia's Food Markets: Practices at Small Community Markets in Yogyakarta. Austrian J. South-East. Asian Stud. 2019, 12, 49-67. [CrossRef] 
73. Tamtomo, K. Unarticulated tensions in the marketization of organic agriculture: The case of pioneer organizations in Yogyakarta, Indonesia. South East Asia Res. 2021, 29, 195-213. [CrossRef]

74. BSN. Badan Standardisasi Nasional, Jakarta Standar Nasional Indonesia (SNI) Sistem Pertania Organik [Organic Food System]. 2016. Available online: http:/ / nasih.staff.ugm.ac.id/wp-content/uploads/SNI-6729--2016-sistem-pertanian-organik.pdf (accessed on 26 June 2021).

75. Rozaki, Z.; Triyono, D.; Indardi; Salassa, D.I.; Nugroho, R.B. Farmers' responses to organic rice farming in Indonesia: Findings from central Java and south Sulawesi. Open Agric. 2020, 5, 703-710. [CrossRef]

76. Shiotsu, F.; Sakagami, N.; Asagi, N.; Suprapta, D.N.; Agustiani, N.; Nitta, Y.; Komatsuzaki, M. Initiation and Dissemination of Organic Rice Cultivation in Bali, Indonesia. Sustainability 2015, 7, 5171-5181. [CrossRef]

77. Nugraheni, S.; Purnama, A. Problems and prospects of organic farming in Indonesia: Lessons from five districts in West Java province. Bina Ekonomi 2013, 17, 112-120. Available online: https://journal.unpar.ac.id/index.php/BinaEkonomi/article/view/ $810 / 794$ (accessed on 8 November 2021).

78. Leksono, A.S.; Mustafa, I.; Gama, Z.P.; Afandhi, A.; Zairina, A. Organic cocoa farming in Indonesia: Constraints and development strategies. Org. Agric. 2021, 11, 445-455. [CrossRef]

79. Hérique, O.; Faysse, N.A. Large-scale public programme to promote organic rice farming in Thailand: Building solid foundations to enable farmers to engage? Org. Agric. 2021, 11, 27-40. [CrossRef]

80. Alrøe, H.F.; Noe, E. What makes organic agriculture move: Protest, meaning or market? A polyocular approach to the dynamics and governance of organic agriculture. Int. J. Agric. Resour. Gov. Ecol. 2008, 7. [CrossRef]

81. Reuter, T. Understanding Food System Resilience in Bali, Indonesia: A Moral Economy Approach. Cult. Agric. Food Environ. 2018, 41, 4-14. [CrossRef]

82. Najib, M.; Sumarwan, U.; Septiani, S.; Waibel, H.; Suhartanto, D.; Fahma, F. Individual and Socio-Cultural Factors as Driving Forces of the Purchase Intention for Organic Food by Middle Class Consumers in Indonesia. J. Int. Food Agribus. Mark. 2021, 1-22. [CrossRef]

83. David, W.; Ardiansyah, N. Perceptions of young consumers toward organic food in Indonesia. Int. J. Agric. Resour. Gov. Ecol. 2017, 13, 315. [CrossRef]

84. Slamet, A.S.; Nakayasu, A.; Bai, H. The Determinants of Organic Vegetable Purchasing in Jabodetabek Region, Indonesia. Foods 2016, 5, 85. [CrossRef]

85. Setiadi, S. Social Entrepreneurship in the Leadership of Grassroots Innovation Movement: A Case Study of Joglo Tani in Yogyakarta. J. Hum. 2020, 32, 259-270. [CrossRef]

86. Fisher, M.; Holden, S.T.; Thierfelder, C.; Katengeza, S.P. Awareness and adoption of conservation agriculture in Malawi: What difference can farmer-to-farmer extension make? Int. J. Agric. Sustain. 2018, 16, 310-325. [CrossRef]

87. Hörner, D.; Bouguen, A.; Frölich, M.; Wollni, M. The Effects of Decentralized and Video-Based Extension on the Adoption of Integrated Soil Fertility Management_Experimental Evidence from Ethiopia; National Bureau of Economic Research: Cambridge, MA, USA, 2019. [CrossRef]

88. Jones, S. A Framework for Understanding On-farm Environmental Degradation and Constraints to the Adoption of Soil Conservation Measures: Case Studies from Highland Tanzania and Thailand. World Dev. 2002, 30, 1607-1620. [CrossRef]

89. Lee, D.R. Agricultural Sustainability and Technology Adoption: Issues and Policies for Developing Countries. Am. J. Agric. Econ. 2005, 87, 1325-1334. [CrossRef]

90. Bridle, L.; Magruder, J.; McIntosh, C.; Suri, T. Experimental Insights on the Constraints to Agricultural Technology Adoption; UC Berkeley: Center for Effective Global Action: Berkeley, CA, USA, 2020. Available online: https://escholarship.org/uc/item/ 79w3t4ds (accessed on 1 April 2021).

91. Magruder, J.R. An Assessment of Experimental Evidence on Agricultural Technology Adoption in Developing Countries. Annu. Rev. Resour. Econ. 2018, 10, 299-316. [CrossRef]

92. Hoffmann, S.; Pohl, C.; Hering, J.G. Methods and procedures of transdisciplinary knowledge integration: Empirical insights from four thematic synthesis processes. Ecol. Soc. 2017, 22. [CrossRef]

93. Bärnthaler, R. Conflict, Controversy, Compromise, and Compression: The Pragmatics of Transdisciplinary (Development) Projects. Austrian J. South-East. Asian Stud. 2020, 13, 193-210. [CrossRef]

94. Popa, F.; Guillermin, M.; Dedeurwaerdere, T. A pragmatist approach to transdisciplinarity in sustainability research: From complex systems theory to reflexive science. Futures 2015, 65, 45-56. [CrossRef]

95. Erbaugh, J.; Bierbaum, R.; Castilleja, G.; da Fonseca, G.A.; Hansen, S.C.B. Toward sustainable agriculture in the tropics. World Dev. 2019, 121, 158-162. [CrossRef] 